\title{
Why More Employers Are Getting SALT-y on Remote Work Arrangements
}

Richard Pomp

University of Connecticut School of Law

Jeffrey A. Friedman

Follow this and additional works at: https://opencommons.uconn.edu/law_papers

Part of the Taxation-State and Local Commons

\section{Recommended Citation}

Pomp, Richard and Friedman, Jeffrey A., "Why More Employers Are Getting SALT-y on Remote Work Arrangements" (2020). Faculty Articles and Papers. 537.

https://opencommons.uconn.edu/law_papers/537 


\section{Why More Employers Are Getting SALT-y on Remote Work Arrangements}

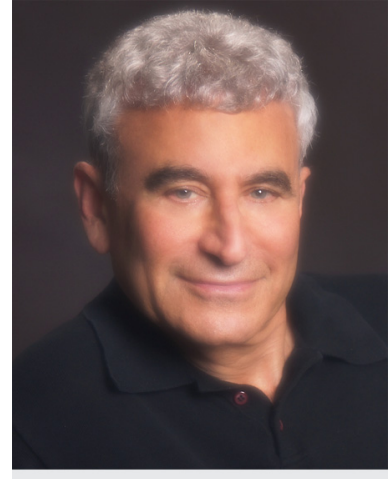

Richard D. Pomp

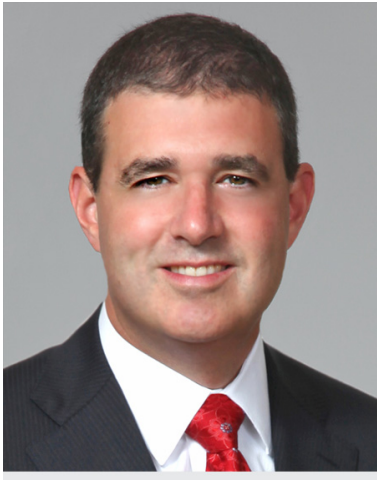

Jeffrey A. Friedman
Richard D. Pomp is the Alva P. Loiselle Professor of Law at the University of Connecticut School of Law, and Jeffrey A. Friedman is a partner in the Washington office of Eversheds Sutherland (US) LLP.

Large-scale remote work experiments have been commonplace for a while, particularly for white collar or knowledge-work positions that can be done from any location with internet access. However, an unprecedented number of U.S. workers were drafted into a massive experiment this year as the COVID-19 pandemic shuttered the offices of nonessential businesses across the country. Employees and their employers are just beginning to fully grasp the potential tax implications of this new, and perhaps not-so-temporary, work environment.

We provide an overview of the key state and local tax issues created by remote employees, including employer withholding and personal and corporate nexus.

\section{Sourcing and Apportioning Nonresident Wage Income}

The pandemic exacerbates many long-standing tensions arising out of nonuniform sourcing and apportionment rules for nonresident employment compensation. We expect to see an uptick in litigation in the coming years arising out of the trailing nexus issues created by states seeking to cling onto their nonresident commuter income tax bases, despite these employees having abandoned their prior in-state locations.

Most states impose an income tax on both residents and nonresidents. Typically, individuals are taxed by their states of residence or domicile on their worldwide income, with credits provided for income taxes paid to other states on the same income. Nonresident employees are taxed on a "source basis," the amount of their wages attributable to their services performed in a state. Such wage income often is determined by looking to the percentage of an individual's working days in the state compared with the individual's working days everywhere. ${ }^{16}$

States use different methods in determining a nonresident's in-state working days. And, in at least five states, a nonresident employee does not need to be physically present in the state for her wages to be subject to tax. ${ }^{17}$

Most notably, New York uses the "convenience of the employer" rule. This rule applies to employees who are assigned to a New York work location but also work at their homes (or other locations) outside New York. The convenience of the employer rule includes as New York working days those days worked outside New York if the employee's non-New York location was for his convenience, and not required by his employer. ${ }^{18}$ This approach has been challenged without success. ${ }^{19}$ But COVID-19 should be the exception. If the New York office is closed and taxpayers are told to work remotely, they are not doing so for their convenience.

Treating individuals as still working at their now abandoned (at least temporarily) offices leads to unfair and illegal results. Solely for purposes of the COVID-19 pandemic, through December 31, Massachusetts issued an emergency rule that

\footnotetext{
${ }^{16}$ Special rules are often applicable to professional entertainers and athletes, commissioned salespersons, and some transportation workers. See, e.g., 830 Mass. Code Regs. section 62.5A.1(5)(b), (c), (e).

${ }^{17}$ See Arkansas Department of Finance and Administration, supra note 3 .

${ }^{18}$ N.Y. Comp. Codes R. \& Regs. tit. 20, section 132.18(a). This regulation provides that "any allowance claimed for days worked outside New York State must be based upon the performance of services which of necessity, as distinguished from convenience, obligate the employee to out-of-state duties in the service of his employer." Other states with similar tests include Connecticut, Delaware, Pennsylvania, and Nebraska. If the arrangement is for the employee's convenience, not necessity, then the adopting state provides that those days will be deemed to occur in the "home office" state for purposes of nonresident source taxation.

${ }^{19}$ See Zelinsky v. Tax Appeals Tribunal, 1 N.Y.3d 85 (2003), cert. den. 541 U.S. 1009 (2004); Huckaby v. New York, 4 N.Y.3d 427 (2005), cert. den. 546 U.S. 976 (2005); Carpenter v. Chapman, 276 A.D. 634 (1950); Manohar and Asha Kakar, State of New York, Division of Tax Appeals, Small Claims Determination, No. 820440 (Feb. 16, 2006).
} 
continues to treat a nonresident - ordinarily working in that state, but who now works remotely for the same employer - as nonetheless continuing to generate in-state taxable income. ${ }^{20}$

This approach - trailing nexus on steroids seems to be constitutionally defective. The due process clause requires that a taxpayer's income have a minimum connection to the taxing state. ${ }^{21}$ Treating a remote worker's income as having a source at the worker's former office location when that worker is prohibited from working there cannot be described as minimally connected (or connected at all) to the taxing state.

The resulting tax also seems to be unfairly apportioned, violating the commerce clause. ${ }^{22}$ Not surprisingly, Massachusetts' position is opposed by New Hampshire, which does not tax wage income earned from personal services. ${ }^{23}$ (Presumably, Massachusetts will tax a nonresident who is temporarily working remotely for her New York-based employer from her vacation home on the Cape.)

\section{Employer Withholding Tax Obligations}

Withholding collects a tax already owed. Consequently, any uncertainty about whether a remote employee can be taxed by a state where her services were previously - but not currently - performed, raises issues about the withholding obligation.

While a significant majority of states have not yet issued COVID-19 guidance related to withholding, some states have recently required withholding for temporary, pandemic-related, remote work arrangements, which implicitly means that remote employees will continue to be taxed on their wages based on the location of their primary work location prior to the pandemic.

\footnotetext{
${ }^{20} 830$ Mass. Code Regs. section 62.5A.3: Massachusetts Source Income of Non-Residents Telecommuting Due to COVID-19 (Emergency Regulation).

${ }^{21}$ Allied-Signal Inc. v. Director, Division of Taxation, 504 U.S. 768, 777778 (1992) citing Miller Brothers Co. v. Maryland, 347 U.S. 340, 344-345 (1954).

${ }^{22}$ South Dakota v. Wayfair Inc., 585 U.S.___, 138 S. Ct. 2080, 2091 (2018), citing Complete Auto v. Brady, $430 \mathrm{U} . \mathrm{S}$. at 279.

${ }^{23}$ New Hampshire Attorney General, Comments on Proposed Regulation 830 CMR 62.5A.3 (Aug. 21, 2020).
}

- Massachusetts, ${ }^{24}$ Mississippi, ${ }^{25}$ and South Carolina $^{26}$ are among several states that now require businesses to continue withholding for employees previously working in the state who are now temporarily working remotely. These states have adopted a temporary trailing nexus policy, in whole or in part, during the COVID-19 pandemic. The guidance issued by these states has important nuances that may affect an employer's withholding obligations, such as exceptions to, and duration of, the policy.

- The New Jersey Division of Taxation distinguishes between someone who works in New Jersey but lives in another state, and someone who lives in New Jersey but works in another state. The division said it would not require employers to withhold on employees previously assigned to a $\mathrm{New}$ Jersey office but now teleworking out of state. ${ }^{27}$ However, the division will source wage income "as determined by the employer in accordance with the employer's jurisdiction." ${ }^{28}$ That is, if a New Jersey teleworker is subject to New York income tax withholding as a result of the convenience of the employer test, New Jersey will not tax the New Jersey-source wages during the "temporary period of the COVID-19 pandemic." ${ }^{29}$

- Illinois, ${ }^{30}$ Minnesota, $^{31}$ and Maryland ${ }^{32}$ have indicated that employers with remote employees now working in these states would be subject to wage withholding

\footnotetext{
${ }^{24}$ See 830 Mass. Code Regs. section 62.5A.3, supra note 20.

${ }^{25}$ Mississippi Department of Revenue, “Mississippi Department of Revenue Response to Requests for Relief" (Mar. 26, 2020).

${ }^{26}$ South Carolina DOR, SC Information Letter No. 20-11 (May 15, 2020) (extended to Dec. 31, 2020, by SC Information Letter No. 20-24 (Aug. 26, 2020)).

${ }^{27}$ The division also appropriately notes that New Jersey's reciprocity agreement with Pennsylvania would apply in many cases. See New Jersey Division of Taxation, Telecommuter COVID-19 Employer and Employee FAQ (last updated May 27, 2020).

${ }^{28}$ Id.

${ }^{29} \mathrm{Id}$.

${ }^{30}$ Illinois DOR, FY2020-29 (May 20, 2020).

${ }^{31}$ Minnesota DOR, COVID-19 FAQs for Individuals (last updated Aug. 20, 2020). Minnesota provides that a nonresident teleworker temporarily in Minnesota may need to apportion income based on the percentage of days worked in the state.

${ }^{32}$ Comptroller of Maryland, Tax Alert 4-14-20B (Apr. 14, 2020).
} 
obligations. In other words, these states have implicitly said that they will enforce their general source-based taxation rules. However, because these states have entered into reciprocity agreements with some of their neighboring states, employers may not need to change state withholding for many employees. $^{33}$

- Ohio passed legislation providing that pandemic-related remote work does not count toward the 20-day withholding threshold for municipal income taxes in teleworking locations. ${ }^{34}$ Legislation has been introduced to repeal this new law ${ }^{35}$ and a think tank has filed a lawsuit challenging it. ${ }^{36}$

Much of the available state guidance is premised on the assumption that employers know where their employees are working remotely. To comply with state withholding obligations related to temporary and, perhaps more importantly, longer-term telework, an employer should consider reviewing the accuracy of employee records and evaluate the company's remote work and travel policies. Imposing a withholding requirement when the employer cannot determine where the remote employee is working is problematic.

\section{Corporate Income Tax and Sales/Use Taxes}

The presence of a single remote employee working for an out-of-state corporation might create nexus for the employer, triggering filing and perhaps payment of a corporate income tax. These employees may also create sales tax collection obligations even for employers that do not meet post-Wayfair nexus statutes. ${ }^{37}$

In 1975 the U.S. Supreme Court held that a single employee operating out of his home was sufficient for Washington to impose its business and occupation tax on the employer. ${ }^{38}$ More recently, in 2010 the New Jersey Tax Court held that an out-of-state company was subject to New Jersey corporation business tax because it permitted one of its full-time software developers to work remotely from her New Jersey home. ${ }^{39}$ In both of these cases, however, the employees were residents of the taxing states and not working there temporarily due to a pandemic.

The District of Columbia, ${ }^{40}$ Indiana, ${ }^{41}$ North Dakota, $^{42}$ and South Carolina ${ }^{43}$ indicated that they will not impose corporate income tax nexus because of the temporary presence of employees with pandemic-related telework arrangements. Oregon also stated that the presence of teleworking employees in Oregon between March 8 and November 1 will be ignored for determining corporate tax nexus if the employees are regularly based outside Oregon. ${ }^{44}$ However, many states have not issued any guidance, leaving taxpayers to speculate (and be second-guessed) about their compliance obligations.

\section{More to Come}

As states and localities continue to adjust to the changes in the pandemic work environment, more guidance will be forthcoming. States might modify or reverse their tax positions as the economic consequences of the pandemic become clearer and if "temporary" telework arrangements continue into 2021, and perhaps become permanent.

\footnotetext{
${ }^{37}$ See Richard D. Pomp, “Wayfair: Its Implications and Missed Opportunities," State Tax Notes, June 10, 2019, at p. 917.

${ }^{38}$ Standard Pressed Steel Co. v. Washington Department of Revenue, 419 U.S. 560 (1975).

${ }^{39}$ Telebright, 38 A.3d 604.

${ }^{40}$ District of Columbia Office of Tax and Revenue, "OTR Tax Notice 2020-05 COVID-19 Emergency Income and Franchise Tax Nexus" (Apr. 10, 2020).

${ }^{41}$ Indiana DOR, Coronavirus Information (last updated Sept. 4, 2020).

${ }^{42}$ North Dakota DOR, COVID-19 Taxpayer Guidance (last visited Aug. 31, 2020).

${ }^{43}$ SC Information Letter No. 20-11, supra note 26.

${ }^{44}$ Oregon DOR, COVID-19 Tax Relief Options (last visited Aug. 31, 2020).
} jurisd tax in the source state. Delaware is the only bordering Michigan, Ind Wisconsin but not with Indith with lowa, Kentucky, will waive penalties and interest for out-of-state employers who fail to thhold tax for temporary telework arrangements in Illinois.

${ }^{34}$ Ohio H.B. 197 (effective Mar. 27, 2020). For municipal income tax work at a temporary worksite due to the pandemic as being earned at the employee's principal place of work.

${ }^{35}$ Ohio S.B. 352 (introduced Aug. 11, 2020).

${ }^{36}$ Buckeye Institute v. Kilgore, Columbus City Auditor, Case No. 20-CV4301, Franklin Ct. of Common Pleas. 